\title{
Towards Increasing Upper Egyptian Student Teachers' Potentials to Emerge into the 21st Education Platform
}

\author{
Hanan Salah El-Deen Mohammed El-Halawany ${ }^{1}$ \\ ${ }^{1}$ School of Education, Asyut University, Asyut, Egypt \\ Correspondence: Hanan Salah El-Deen Mohammed El-Halawany, School of Education, Asyut University, 71515 \\ Asyut, Egypt. Tel: 20-10-2231-2454. E-mail: hananelahalawany6@gmail.com
}

Received: April 24, 2018

Accepted: June 29, $2018 \quad$ Online Published: September 27, 2018

doi:10.5539/ies.v11n10p1

URL: https://doi.org/10.5539/ies.v11n10p1

\begin{abstract}
The Ministry of Education in Egypt (MOE) has worked very hard to launch different initiatives to improve the Egyptian education system by using Information and Communication Technology (ICTs).

The current research seeks to explore how Asyut student teachers perceive the upshots of these initiatives. Results are expected to shed light on the overall teacher education process in Asyut University and its role in preparing 21 st century teachers.

The current research is evolved to answer the following questions:

1) How Asyut student teachers describe their investment of ICTs to achieve academic purposes?

2) How Asyut student teachers describe their ICTs competencies?

3) How Asyut student teachers classify obstacles hindering the enhancement of their ICTs competencies?

Results authenticate the growing awareness Asyut student teachers developed about ICTs and how it has become a substantial component of everyday 21 st century education experience. They understand that it has become their gateway to the 21 st century teaching platform. In the meantime, they recognize that their ability to successfully integrate ICTs into their teaching practice is a complex and multifaceted process.

The current research adds to the body of literature in a few ways. Through analyzing the gains and drawbacks, Egyptian teacher education experienced in its attempt to integrate ICTs into teachers' preparation process. The current research recommends: first, improving the existing training mechanism; second, ensuring funds will have the biggest impact on the largest number of student teachers; finally, getting training right is a priority.
\end{abstract}

Keywords: Upper Egypt, student teachers, 21st century education, ICTs, Asyut University

\section{Introduction and Theoretical Background}

The emergence into the $21^{\text {st }}$ century, where societies transform into information and innovations-based ones, put a huge demand on the education system to continuously improve itself to be able to deal with the complexity and flexibility of this new era. Teaching and learning ought to change to create a high-quality manpower capable of competing in the global labor market. In other words, education systems need to produce a workforce able to create, invent, innovate, and solve problems (Husin et al., 2016).

Egypt is largest Arab country with 85 million people two third of whom are under 25. Therefor Egyptian youth are perceived as Egypt's best assets and wealth resources. Currently Egypt has 18 state universities and 16 private universities producing 300,000 graduates every year, many of whom are stuck in the unemployment whirlpool. Employers claim that they have difficulty in hiring university graduates because they do not possess the required $21^{\text {st }}$ century skills. They confess that university graduates possess the required knowledge, but they have difficulties in transcending this knowledge to the work place. In other words, they claim that university graduates lack experiential education that blends theoretical knowledge with world experiences (Kirby \& Ibrahim, 2012, p. 100).

This means that the Egyptian education system need to change to produce a workforce capable of creating, innovating, thinking critically, and capable of solving problems. A Workforce that can see available opportunities, take advantages of changes in labor market, and take risk of leaving the comfort zoon of governmental job sector to 
emerge into the world of entrepreneurship and freelancing (Hattab, Krby, Gohar, \& EL Shorbagi, 2012).

Timmons (1989) defines entrepreneurship and freelancing as, "the ability to create and build something from practically nothing. It is initiating, doing, achieving, and building an enterprise or organization, rather than just watching, analyzing or describing one. It is a knack for sensing an opportunity, where others see chaos, contradiction and confusion" (p. 1).

In the current digital world entrepreneurship and freelancing are synchronized with other competencies as: communicating with others; analyzing and interpreting enormous amounts of data; think critically; reflect and evaluate learning materials in real life situation. Therefore, $21^{\text {st }}$ century education must be grounded on preparing creative open mind manpower that is willing to appreciate exploring new and daring ideas (Henriksen, Mishra, \& Fisser, 2016; Husin et al., 2016).

To respond to these challenges the Egyptian government has made a strong commitment to renovate its education system through integrating Information and Communication Technologies (ICTs) in the educational process. They have a deep convection that ICTs will inspire and empower both teachers and students to transform teaching and learning performance from a teacher-centered into a student-centered process which will foster students' creativity, innovation, problem-solving, and other higher-order thinking skills (Minstry of Communications and Information Technology, 2006; Trucano, 2005).

The Ministry of Education in Egypt (MOE) has worked very hard to turn this vision into reality. It launched different initiatives to improve the Egyptian education system by using Information and Communication Technology (Marsh, 2014).

In 2008, Egypt at the World Economic Forum on the Middle East, celebrated launching the Egyptian Education Initiative (EEI) under the umbrella of the Global Education Initiative aiming to reform the Egyptian Education system by using ICTs (World Economic Forum, 2009). The EEI initiative was meant to address different challenges among them the issue of raising the level of effectiveness and efficiency of education. It also aimed to stimulate learning skills, provide equitable and high-quality education for all Egyptians regardless of their socioeconomic status, geographical location, and gender.

Upon that the Egyptian government worked on establishing the required infrastructure to facilitate the integration of ICTs into all education institutions specially universities. These efforts can be summarized in the following points (MCIT, 2008, 2010):

- Providing all educational institutions with high-speed internet networks;

- Establish students' computer labs;

- Preparing training program for all educators and administrators to use ICTs efficiently;

- Encouraging the transformation of traditional courses into electronic interactive courses.

Nevertheless, the challenges of incorporating technologies into education do not only depend on stuffing schools and universities with ICTs equipment, but it is rather a long-term, tedious, multiphase process (Yuksel, Yildirim, \& Yildirim, 2009). In making Better Connections, Downs (2002) identifies three steps for an education system to avail of integrating ICTs: 1) Using ICTs to enhance students' abilities within the existing curriculum. 2) Using ICTs to enhance students' abilities as an integral component of broader curriculum reforms that are changing not only how learning occurs but what is learned. 3) Using ICTs as an integral component of the reforms that alter the organizational structure of schooling itself (p. 23).

Teachers are the pillars of any educational transformational strategy. In the current context, they are expected to provide an example in adapting and interacting efficiently with ICTs; project $21^{\text {st }}$ century merits in their teaching and demeanors; and provide students with guidance on how ICTs can be used within the economic and cultural contexts of their societies (Janssens-Bevernage, Cornille, \& Mwaniki, 2010).

Moreover, teachers are obliged to learn how to: analyze and interpret information, make decisions based on the collected information, and master new knowledge to accomplish complex tasks. Most important teacher should be trained on mastering critical thinking to scrutinize learning materials and to decide whether it can be considered a useful input in any learning activity (Bakir, 2016; Derya-Orhan \& Kurt, 2017)

Venkatesh et al. (2016) examined higher education instructors' and students' perceptions of faculty members' proficiency in using ICTs as teaching tools. Results marked instructors' confidence in their ability to use ICTs constructively to create interactive classroom. Students expressed their satisfaction and appreciation with interactive classes that blend traditional instructions with digital resources and material. 
Lee (2000) confirmed that teachers' integration of ICTs into their teaching can significantly contribute to: transforming passive learning into experiential learning, infusing learners' motivation, improving students' academic achievement, providing opportunities for interaction, maintaining balance between local and global components of education, and increasing multicultural appreciation. Therefore, he considered ICTs as a gateway to new horizons for students who are in quest for guidance to "help them traverse the interlacing and challenging roads of the information superhighway".

On the other realm, several researches called attention to the fact that although ICTs can provide innovative techniques for teaching and learning, yet they cannot guarantee the achievement of the intended learning outcomes (Abdelaziz, 2012; Al-busaidi \& Al-shihi, 2012; Brun \& Hinostroza, 2014; Dela Rosa, 2016). Therefore, teachers need to improve their technical skills, because they need to know how computers or other ICT devices work to fully benefit from their potentials in their teaching (Janssens-Bevernage et al., 2010).

However, several factors intervene affecting teachers' ability to fruitfully integrate ICTs in teaching and learning process. Among them are: teachers' lack of ICTs skills; lack of self-confidence; lack of pedagogical teacher training; lack of suitable educational software; limited access to ICTs; rigid structure of traditional educational system; and out dated curricula (Buabeng-Andoh, 2012).

To overcome these obstacles, a summit of California college and university presidents declared its commitments to improve the quality of teacher education and work with policy makers to improve the conditions of teaching in California. University leaders announced their commitments to create powerful teacher education programs that rely heavily on ICTs (Darling-Hammond, 2001).

On the other hand, attitudes towards ICTs are found to be an essential factor influencing teachers' implementation of ICTs into their classroom teaching. Many researches recommended providing student teachers with ICTs instructions and training throughout their curricula, because this appears to have positive impacts on student teachers' attitudes and readiness to integrate ICTs into their future teaching and their future professional upskilling plans (Enochsson, 2010)

Findings emerged from an empirical grounded longitudinal case research conducted over a three period supported the above argument. Researchers worked with one of the earliest schools in New Zealand to introduce a Bring Your Own Device (BYOD) policy. Upon this policy the school directed all its students to bring their own computers in classrooms. Results shed light on key factors affecting the learning process especially how successful integration of computers' use inside classroom has positive impact of both students' and teachers' self-efficacy (Ale, Loh, \& Chib, 2017).

In developing countries context, a group of researchers in Pakistan tried to explore the gains earned form the implementation of ICTs in education in Khyber Pakthunkhwa and Punjab provinces. It was the first time this course, "ICTs in Education", was implemented in an Elementary school. Findings revealed that the program was not properly implemented in most of classrooms. This practical deficiency referred to the lack of electric power supply, scarcity of ICTs equipment, and lack of teachers' training and skills in ICTs application (Muhammad-Iqbal, Fazal, \& Muhammad-Saeed, 2013).

Another study conducted in Gaza Strip in Palestine targeted to explore to what extent the International Society for Technology in Education (ISTE) standards are implemented for teachers and students in technical education colleges in Gaza Strip of Palestine. Results showed low degree of implementation of ISTE standards for both teachers and students in technical colleges. This deficiency was explained in light of the lack of proper ICTs infrastructures as well as insufficient ICTs training programs for both teachers and students that affected they ability to adopt and implement ISTE standards (Fuad-Ismail \& Ajrami, 2017).

From a similar vein, Al-Zawei, Parslow, and Karsten (2016) argued that in the Middle East the implementation of e-learning is still in its infancy stage. They investigated the status of e-learning in public Iraqi universities. They spotted different obstacles that are preventing successful adoption of this technology. Results identified the main common barriers the hinder the implementation of e-learning in most Middle Eastern public university as well as Iraq. The key barriers were identified as followed: low internet bandwidth, insufficient financial revenues, inadequate ICTs infrastructure, and lack of training programs (p. 142).

This literature review marks an important transition in nature of the teaching/learning process in the $21^{\text {st }}$ century. Teachers are no longer perceived as information provider but rather a co-constructor of students' knowledge, whereas teaching has no longer become connected to learning but learning has turned into an independent, self-constructed process (Topolovčan \& Matijević, 2017).

In light on these facts, the current research seeks to explore how Asyut student teachers perceive the upshots 
MOE's efforts to integrate ICTs into Egyptian teacher education. Results are expected to shed light on the overall teacher education process in Asyut University and its role in preparing student teachers to become $21^{\text {st }}$ century teachers.

\subsection{Research Questions}

The current research is evolved to answer the following questions:

1) How Asyut student teachers describe their investment of ICTs to achieve academic purposes?

2) How Asyut student teachers describe their ICTs competencies?

3) How Asyut student teachers classify obstacles hindering the enhancement of their ICTs competencies?

\section{Method and Data Collection Tool}

Initial teacher education programs in Egypt are generally undertaken by Faculties of Education in which student teachers enroll on four-year pre-service programs after obtaining their secondary education certificate. The mission of Faculties of Education is to provide pre-service teacher training that would qualify teachers in all disciplines at a Bachelor level and prepare them to work as teachers at the pre-university educational levels. Schooling in all Egyptian institution can be described as an examination-oriented and content base system. Consequently, all class teaching, and activities are directed to assist students to pass the examination using face to face instructions inhabited in the teacher-centered approach (El Ebyary, 2013, p. 2170).

However, Egypt national ICTs education policies are often linked with the country's ambitious development goals as: supporting economic growth; promoting social development; education reforms; promoting $21^{\text {st }}$ century skills (Pouezevara, Mekhael, \& Darcy, 2014).

Therefore, a pedagogical shift is required to achieve this mission. The integration of ICTs into teacher education is expected to transmit traditional education to become a learner-centered process (Thormann \& Fidalgo, 2014). Instead of passively receiving isolated blocks of information, student teachers are expected to collaborate to construct knowledge. They are also expected to invest ICTs to collect, analyze; interpret; solve problem and then share knowledge (Ladyshewsky, 2006; Murphy \& Rodriguez-Manzanares, 2009).

To explore to what extent initial teacher education in Asyut reflects this pedagogical shift from student teachers' perspectives; a descriptive analytical approach was implemented. To collect data a questionnaire with seven sections was designed. It is widely acknowledged that questionnaires help researchers examine phenomenon, collect data from a representative sample, and then generate results that can be generalized (Robson, 1997). The current questionnaire consisted of seven sections dedicated to collect data describing student teachers' ICTs current and future investment in academic and professional spheres: 1) student teachers' use of computers to achieve academic purposes; 2) student teachers' use of internet to achieve academic purposes ; 3) student teachers' ICTs training experiences; 4) student teachers' self-confidence in their ability to use ICTs for academic purposes; 5) students teachers' perception of the importance of integrating ICTs into their future teaching practice; 6) student teachers' classification of their needs to improve their ICTs competencies; 7) an open ended question dedicated to give student teachers the opportunity to list the most important obstacles hindering the enhancement of their ICTs competencies.

\section{Summary of Participants' Data}

The questionnaires were distributed among 200 fourth year student teachers during the school year 2014/2015. The questionnaire was distributed during their study classes by the researcher. Only student teachers with Math and English majors were selected to participate in the research; Math to represent the scientific specialization and English to represent humanities.

Table 1. The characteristics of student teachers participated in the research

\begin{tabular}{lcccc}
\hline & Students with English as major & Code & Students with Math as major & Code \\
\hline Male & 50 & Male of English Major (EM) & 50 & Male of Math major (MM) \\
Female & 50 & Female of English major (EF) & 50 & Female of Math major (MF) \\
\hline
\end{tabular}




\section{Results and Analysis}

Table 2. Student teachers' possession and use of computers

\begin{tabular}{|c|c|c|c|c|c|c|c|c|c|c|c|c|c|c|c|}
\hline & \multicolumn{6}{|c|}{ Possession of computers } & \multicolumn{4}{|c|}{ Use of computers in study } & \multicolumn{2}{|c|}{$\begin{array}{c}\text { Average hours of } \\
\text { using computers per } \\
\text { week }\end{array}$} & \multicolumn{3}{|c|}{$\begin{array}{l}\text { Access to university computer } \\
\text { laps }\end{array}$} \\
\hline & DT & LT & Both & Neither & Never & Rarely & $\begin{array}{l}\text { Less } \\
\text { than } \\
\text { half } \\
\text { Time }\end{array}$ & $\begin{array}{l}\text { About } \\
\text { half the } \\
\text { time }\end{array}$ & $\begin{array}{l}\text { More } \\
\text { than } \\
\text { half the } \\
\text { time }\end{array}$ & always & Study & personal & $\begin{array}{c}\text { No } \\
\text { access }\end{array}$ & $\begin{array}{l}\text { Restricted } \\
\text { with fees }\end{array}$ & Free \\
\hline EM & $70 \%$ & $5 \%$ & $10 \%$ & $15 \%$ & $50 \%$ & $15 \%$ & $30 \%$ & $5 \%$ & $0 \%$ & $0 \%$ & 3.1 & 13.2 & $45 \%$ & $50 \%$ & $5 \%$ \\
\hline MM & $65 \%$ & $0 \%$ & $0 \%$ & $35 \%$ & $50 \%$ & $30 \%$ & $10 \%$ & $0 \%$ & $0 \%$ & $10 \%$ & 2.15 & 16.4 & $15 \%$ & $65 \%$ & $20 \%$ \\
\hline $\mathrm{EF}$ & $56 \%$ & $0 \%$ & $4 \%$ & $40 \%$ & $42 \%$ & $36 \%$ & $6 \%$ & $2 \%$ & $0 \%$ & $14 \%$ & 2 & 10.7 & $8 \%$ & $74 \%$ & $18 \%$ \\
\hline MF & $64 \%$ & $11 \%$ & $0 \%$ & $25 \%$ & $42 \%$ & $44 \%$ & $11 \%$ & $0 \%$ & $3 \%$ & $0 \%$ & 1.9 & 3.1 & $33 \%$ & $58 \%$ & $8 \%$ \\
\hline
\end{tabular}

DT: Disk top computer; LT: Lap top computer.

Table 2 shows that most students of both English and Math majors possess disk top computers where lap tops are less common among all student teachers of both majors. Whereas, a considerable proportion of female student teachers of both majors disclaimed their possession of any sort of computers. This highlights the fact many student teachers to use computers they need to have access to students' computer laps available in the faculty.

When examining student teachers' opportunities to access university computers laps, the gloomy picture gets darker; as the majority of male and female student teachers of both major expressed that they have a limited access to university's computers laps. They denounced their compulsion to pay a certain amount of money for each hour they spend in computer laps. Therefore, a considerable proportion of Math male and English female student teachers deny having access to university computers laps at all. Taking into consideration that Asyut is one of the poorest governorates in Egypt; this explains why any fee to use university computers laps present a financial burden they cannot afford.

This also explains why most male and female student teachers from both majors expressed that they either never or rarely use computers for academic purposes although they previously stated that they own computers at home.

These facts left its impact on all student teacher's average hours of using computers for academic purposes per week. Whereas, male students of both English and Math majors admit that they spend a considerable mount on time on using computers for personal purposes. Although female student teachers seem to spend less time using computers for personal reasons than male students, yet a significant discrepancy appears between the time English female and Math female student teachers they spend on using computers for personal reasons in favor of English students.

Since 2003 the Egyptian Ministry of Education launched "Egypt PC 2010" initiative. The goal of this project was to provide a computer to every home by 2010 . Computers were sold at a discounted price and paid for in monthly installments starting at LE 43 (\$ 7) per month (MCIT, 2010). This project targets to assist Egyptian families to obtain a desk top computer at a low cost, yet for low income families, most of families in Asyut, the LE 43 per month may present a financial burden.

Table 3. Student teachers' use of internet for academic purposes

\begin{tabular}{lcccccc}
\hline & Never & Seldomly & Less than half the time & Half the time & Usually & Always \\
\hline EM & $0 \%$ & $15 \%$ & $20 \%$ & $20 \%$ & $30 \%$ & $15 \%$ \\
MM & $0 \%$ & $0 \%$ & $0 \%$ & $50 \%$ & $40 \%$ & $10 \%$ \\
EF & $0 \%$ & $0 \%$ & $6 \%$ & $42 \%$ & $36 \%$ & $12 \%$ \\
MF & $6 \%$ & $6 \%$ & $17 \%$ & $39 \%$ & $14 \%$ & $19 \%$ \\
\hline
\end{tabular}

Table 3 results are in harmony with statistical indictors of internet usage and population growth in Egypt that show a rapid expansion of the usage of internet among Egyptians (Internet World States, 2018). In 2000 only $0.7 \%$ of Egyptian used Internet, while in 2012 the ration increased to reach $35.6 \%$. 
Upon that most male and female student teachers from Math and English majors confirmed that they usually use Internet to accomplish academic tasks. Tayie et al. (2012) asserted that Egyptian rural students frequently use Internet in connection with computer to do academic chores. While, urban students spend more time connecting to the internet in connection with mobile phones to play games and interact with their friends and families. Therefore, mobile phones are becoming favorable to Egyptian youth who are becoming more dependable on their mobile devices to accomplish all different sorts of tasks.

Egyptian student teachers, as the rest of the society, are becoming aware of the growing coalescence between ICTs and daily life activities including learning and teaching. This awareness is translated in their recognition of importance their enrollment in ICTs training program.

Table 4. Student teachers with ICTs training

\begin{tabular}{lcc}
\hline & Student teachers with ICTs training & Student teachers without ICTs training \\
\hline EM & $80 \%$ & $20 \%$ \\
MM & $70 \%$ & $30 \%$ \\
EF & $90 \%$ & $10 \%$ \\
MF & $78 \%$ & $22 \%$ \\
\hline
\end{tabular}

Table 4 shows that most male and female student teachers from Math and English majors acquired a sort of a ICTs training, even though if this training was very basic like the ICDL. Table 3 and Table 4 shed light on the growing recognition of Egyptian student teachers of the importance of "learning about, from and with ICTs" (Rautopuro, Pöntinen, \& Kukkonen, 2006, p. 286). Learning about ICT refers to the type of training that focuses on ICTs' acquisition skills. Learning from ICTs refers to the type of training that targets to change student teachers' academic behavior as a result of using ICTs. Finally, learning with ICTs refers to the constructive implementation of ICTs to accomplish learning objectives. All three forms of learnings signal a comprehensive transformation in the accustomed traditional Egyptian teacher education, as student teachers are now moving away from being passive learner and becoming active knowledge constructing agents.

Egyptian student teachers growing investment of the internet in their academic activities signified a very important transformation in student teachers' perceptions of their role as learners. Numbers gave evidences that they are engaging more in a self-regulated, non-linear, and interpretive process of constructing knowledge supported by their increasing use of the internet to accomplish academic activities (Fosnot \& Perry, 2005). This educational transformation has positively affected Egyptian student teachers' self confidence in their ICTs proficiency.

Table 5. Student teachers' self-confidence in their ability to use ICTs for academic purposes

\begin{tabular}{lcccc}
\hline & Low & Medium & High & Very High \\
\hline EM & 0 & $15 \%$ & $35 \%$ & $50 \%$ \\
MM & $15 \%$ & $15 \%$ & $45 \%$ & $25 \%$ \\
EF & 0 & $6 \%$ & $58 \%$ & $36 \%$ \\
MF & $11 \%$ & $6 \%$ & $39 \%$ & $44 \%$ \\
\hline
\end{tabular}

Results presented in Table 5 show that most of male and female student teachers in Math and English majors are expressing their confidence in their ability to successfully use ICTs to improve their academic performance. Confidence in this case means the ability to use computers and becoming at ease using them (Chen \& Chang, 2008). Building teachers' confidence is the key to 21 st century education because they become welling to challenge themselves and develop and try new teaching skills.

Table 6. Student teachers' perceptions of the importance of integrating ICTs into their future teaching practice

\begin{tabular}{lcccc}
\hline & Insignificant & Partly Significant & Significant & Very Significant \\
\hline EM & 0 & $15 \%$ & $40 \%$ & $45 \%$ \\
MM & 0 & $10 \%$ & $25 \%$ & $65 \%$ \\
EF & 0 & $16 \%$ & $36 \%$ & $48 \%$ \\
MF & 0 & $17 \%$ & $25 \%$ & $58 \%$ \\
\hline
\end{tabular}


21 st century teachers are expected to acquire the knowledge, attitude, and skills to use ICTs efficiently in their teaching practice. Table 6 shows that most student teachers of both Math and English Majors recognize the inevitable importance of integrating ICTs into teaching. This also reflects student teacher's awareness that teaching as profession has currently exceeded the traditional meaning of teaching that limited teaching to presenting knowledge and following the school curriculum. It is now becoming an extension of continuously developing pedagogical role. This requires teachers to change their teaching techniques and adopt new methods of teaching that depend on ICTs (Kalogiannakis, 2010).

However, integrating ICTs into student teachers' daily academic and professional activities is still a challenging process. Constant effort is still needed to empower and fully prepare them to effectively incorporate ICTs in their teaching. Student teachers are aware of many of these challenges; they arrange them in a hierarchical order according to their importance as followed.

Table 7. Student teachers demand free access to University computer laps

\begin{tabular}{lcccc}
\hline & Insignificant & Partly Significant & Significant & Very Significant \\
\hline EM & $0 \%$ & $0 \%$ & $20 \%$ & $80 \%$ \\
EF & $0 \%$ & $2 \%$ & $10 \%$ & $88 \%$ \\
MM & $10 \%$ & $0 \%$ & $30 \%$ & $60 \%$ \\
MF & $3 \%$ & $0 \%$ & $14 \%$ & $83 \%$ \\
\hline
\end{tabular}

Table 8. Student teachers demand training courses on the pedagogical use of ICTs

\begin{tabular}{lllll}
\hline & Insignificant & Partly Significant & Significant & Very Significant \\
\hline EM & $0 \%$ & $0 \%$ & $30 \%$ & $70 \%$ \\
EF & $0 \%$ & $2 \%$ & $18 \%$ & $80 \%$ \\
MM & $10 \%$ & $0 \%$ & $20 \%$ & $70 \%$ \\
MF & $0 \%$ & $3 \%$ & $28 \%$ & $69 \%$ \\
\hline
\end{tabular}

Table 9. Student teachers demand an access to high quality ICTs equipment for their field practice

\begin{tabular}{lcccc}
\hline & Insignificant & Partly Significant & Significant & Very Significant \\
\hline EM & $0 \%$ & $0 \%$ & $20 \%$ & $80 \%$ \\
EF & $0 \%$ & $2 \%$ & $14 \%$ & $84 \%$ \\
MM & $0 \%$ & $10 \%$ & $35 \%$ & $55 \%$ \\
MF & $3 \%$ & $11 \%$ & $11 \%$ & $75 \%$ \\
\hline
\end{tabular}

Table 10. Student teachers demand of ICTs hands on training program

\begin{tabular}{lcccc}
\hline & Insignificant & Partly Significant & Significant & Very Significant \\
\hline EM & $0 \%$ & $0 \%$ & $40 \%$ & $60 \%$ \\
EF & $0 \%$ & $4 \%$ & $18 \%$ & $74 \%$ \\
MM & $5 \%$ & $0 \%$ & $20 \%$ & $75 \%$ \\
MF & $0 \%$ & $3 \%$ & $31 \%$ & $67 \%$ \\
\hline
\end{tabular}

Tables 7, 8, 9, and 10 asserted the raised assumption that Egyptian student teachers are developing a subtle understanding of the nature of the 21 st century teaching mission. They showed constant evidences of a growing awareness of the existence of many external factors affecting their ICTs proficiency. Among these external factors is the access to computers and software which is the most common one (Hani, 2014). Therefore, student teachers demand a free access to university computer laps which means that Asyut University need to subsidize the Faculty of Education with more computers available for free to all students, Table 7.

Results presented in Table 8 showed that student teachers are becoming fully aware that their roles as $21^{\text {st }}$ century teachers are no longer aligned with the traditional roles assigned for teachers in traditional schools. They understand that ICTs are becoming an integral part of everyday life in modern schools. They recognize that they need an extensive ICTs training to be able to select the appropriate form ICTs that will assist them to transform traditional classrooms into $21^{\text {st }}$ century learning environment (Beriswill, Bracey, Sherman-morris, Huang, \& Lee, 2016). They realize that $21^{\text {st }}$ century education requires "communication competency, analyzing and interpretation 
of data, understanding and assessment of models, task management and task prioritization, involvement in problem solving, and ensuring wellbeing and safety"(Kay \& Honey, 2005).

ICTs present a challenging topic in $21^{\text {st }}$ century teacher education, as teachers need to understand that one of their major responsibilities is to assist their students to understand and to participate in a competitive demanding insecure, rapidly changing world (Chen \& Chang, 2008; Husin et al., 2016). Therefore, future teachers must be trained to be able to "navigate their technological pedagogical content knowledge" (Liu, Baker, \& Milman, 2014, p. 62), because $21^{\text {st }}$ education has become more global, interdisciplinary, and takes a holistic approach. It is moving away from the traditional series of isolated courses that present traditional outdated educational topics. Therefore, student teachers demand the availability of adequate infrastructure and pedagogical training to guide their integration of ICTs into their teaching performance to be able to perform these new roles, Table 9.

To complete the picture, Table 10 reflect student teachers' mounting recognition of their need to an education that moves away focusing on teaching how to integrate ICTs into teaching practice, to a more applied education that focuses on ICTs skills acquisition (Bradshaw, Younie, \& Jones, 2013). Therefore, they raise their demands of hands-on training programs that help them improve their ICTs technical and practical skills.

The above demands are supported by the qualitative results emerged from analyzing student teachers' list of obstacles that jeopardize their ICTs progress. They classified these obstacles as followed:

1) Lack of free access to University computer laps

2) Insufficient ICTs training

3) The mediocre quality of computers in University computer laps

4) Price of personal computers

5) Time limitation

6) Faculty members' old fashion teaching methods

7) Lack of self-confidence

8) In sufficient ICTs equipment for field practice

9) Cultural barriers

10) Type of study

It is obvious from the above list that most student teachers agree that the biggest obstacle jeopardizing their ICTs competencies' development is the lack of free access to University computer laps. One Math student teacher commented on that stating, "Lap top computers are not available and if there is one there are restrictions for using it". Another Math female student teacher explained, "you have to pay a certain amount of money to be allowed to use the lap top computers in University computer laps, and sometimes the lap supervisor refuses to give us the permission to use the equipment because he is afraid that we might sabotage them".

The economic dimension is a major concern of any Egyptian university. It may have fund to provide faculties with computer laps, but it cannot offer the required fund for maintenance and up grading. This drives faculties to consider their computer laps as external sources of revenue; therefore they charge fees for using them (Pouezevara et al., 2014). A Math male student teacher commented on that, "the financial status of the faculty holds back its ability to provide student teachers with proper ICTs equipment".

Taking into consideration the personal financial status of many student teachers, 55 of them believe that it is difficult for them to purchase computers. Therefore, securing a free ICTs access through the university appears crucial to promote their ICTs skills. However, as one English female student declared, "Computer assistants focus their attention on the safety of the equipment rather than assisting students to improve their ICTs competencies".

On the other hand, training is another source of anxiety to many student teachers as 92 of them believe that their privation of appropriate training program is to be blamed for their underdeveloped ICTs skills. This reflects their recognition that a continuous and constant pre-service training is essential for their emergence into $21^{\text {st }}$ century education. Therefore, student teachers expressed their need to raise their ICTs competencies through efficient, hands on training programs and counseling. One English female student commented on that, "the way they teach computer is wrong". Another English female student said, "no ICTs training courses are specified for us".

Other student teachers place the blame of their insufficient ICTs skills on the shoulders of faculty members. They claim that faculty members still depend heavily on oral lecturing and writing on white boards instead of integrating ICTs into their teaching. One English female student commented, "faculty members don't use modern technology 
in their teaching". Another Math female student reported "faculty members are not interested in giving assignments that require the use of ICTs".

Faculty members' attitude toward the integration of ICTs into their teaching and into academic activities, has also affected the nature of the offered courses as one English female student commented, "the courses we are taking are traditional and outdated as they depend mostly on memorization and recitation". Another English female student subjoined "most faculty members are concerned with quantity over quality".

Emerging from a similar vein, 42 student teachers believe that lectures consume their school day sparing them no time to work on improving their ICTs skills. One English female student commented, "the school day is jammed with oral lectures".

Although, cultural barriers appear as a minor obstacle, yet it is very influential especially in reviewing student teachers' comments, especially female students.

Asyut is an Upper Egyptian province, and it is one of the most conservative governorates in Egypt. One Math female student commented, "most families restrict their daughters' use of Internet". Another Math female students explained, "most families usually don't allow their daughters to go to the "Sipper"- private computer centers- to use computers". Another English female student explained this phenomenon, "the predominant perception among families in Asyut is that using technology and surfing the internet are waste time and threatens girls' chastity".

Despite of this list of obstacles, a dazzling change appears in the horizon as one English female student commented, "I don't like technology, but now I like to use it more especially after discovering the role ICTs played in flaming $25^{\text {th }}$ of January revolution that changed the face of Egypt. Although, I prefer reading books, yet now I like to rely more on technology. Before the revolution I was not active because I thought I was worthless. Now I follow news and read articles I find on Twitter and Facebook. I read a lot about politics and try to understand the political and economic situation of Egypt".

\section{Discussion}

Giroux (2005) argued that education in the $21^{\text {st }}$ century should provide students with enough space to engage in an ongoing dialogue, challenge them to think critically about the received knowledge, and stimulate their power to become socially active agents. "Pedagogy has a relationship to social change in that it should not only help students frame their sense of understanding, imagination, and knowledge within a wider sense of history, politics, and democracy but should also enable them to recognize that they can do something to alleviate human suffering and promote social justice" (p19).

On January 25, 2011, all world media broadcasted news and videos of Egyptian youth uprising. The world watched the crowds in Tahrir Square striving to overthrow President Hosni Mubarak and put an end to his 30 years of domination. After 18 days of protesting, Egyptians succeeded in forcing Mubarak to step down. In this revolution Facebook and Twitter were used to spread the revolution messages; five million Egyptians were mobilized by social media. Now this revolution is globally known as the internet and social media revolution.

Internet use in Egypt is expanding very fast. In 2000 there were almost 450,000 users. This number increased in 2006 to 6 million, 10.5 million in 2008, 17 million in 2010, 21 million in 2011, and 6,318,355 in 2017 (Internet World States, 2018). However, digital inequality remains as a large percentage of young population experience digital exclusion due to poverty, geographic location, and other cultural factors (Herrera, 2012).

Asyut student teachers' responses sustain the above argument where a sizable proportion expressed their frustration from their deprivation of possessing a personal computer or other ICT devices that limit their chances to connect with the world. Things get even worse for female who are burdened with economic and cultural constrains. Despite that, Asyut youth interacted with the digital invitation to apprise against Mubarak regime likewise other Egyptians.

All protesters in January 25 called for a comprehensive reform in all country's systems. The call for an educational reform was on the top of protestors' list of demands. However, reform was not a quick or feasible process at that time especially after the Muslim Brotherhood purloined the revolution and dragged the whole country into a dark tunnel and assassinated Egyptians' dreams of establishing a prosperous progressive country.

In June 30, 2013 Egyptian people for the second time overthrew Dr. Mohamed Morsi, the Muslim Brotherhood representative, who tried to impose his organization conservative and fundamentalist agenda. It was a very stressful and dangerous movement that required the interference of the Egyptian army. Again, people were mobilized with social media that empowered and encouraged them to participate in street demonstrations demanding the Muslim Brotherhood Organization to step down. 
All these uprisings actions were not without economic consequences, they cost Egypt about $\$ 90$ million (Udanor, Aneke, \& Ogbuokiri, 2016). This financial burden has affected the country's reformation plans including educational.

Waly (2013) examined the pedagogical shift in Egyptian education after two revolutions, and she confirmed that many teachers adopted teaching styles revolved around freedom of choice and expression. Class discussion evolved around political and economic issues that were considered taboos before. Such changes deepened students' understanding of the changes sweeping their society and allow them to renegotiate their roles as activists and agents of change. They also configured the power of ICTs not only as tools of communication and mobilization but also as vehicles of transcending ideas, values, and believes (Marsh, 2014; Sallam, 2013).

Student teachers participated in this research are vivid examples of the growing awareness that distinguished the Egyptian society after two revolutions. They have turned into active empowered agents who can freely and openly criticize the existing teacher education system. In their responses they attacked faculty members accusing them of being unqualified and under-motivated. They declared that the existing teacher education curriculum is irrelevant and outdated; lack practical skills formation; concentrate on memorizing bulks of meaningless information; use passive pedagogies, and lack constructive investment of ICTs. Consequently, student teachers give evidences of their recognition of the existence of a significant mismatch between the expected educational reform and the skills they are developing.

They recognize that they need to excel in computer and information technology in case they want to improve their employability skills (Coplin, 2003). They understand clearly that university graduates, regardless of their specialization, should enhance their employability skills. Employers want to hire "graduates with personal potential who perform well in daily business and take initiatives, no matter which grade or specialization they acquired" (Schomaker, 2015, p. 153). Upon that, all Egyptian higher education institutions including Faculties of Education will be on societal trial until they respond to the current socioeconomic changes.

This situation grows tense as Egyptian youth are turning into digital vanguard employing ICTs as opposition weapon, using them to build coalitions and to lead civil disputes. In other words, ICTs has become a medium for social empowerment, consciousness formation, and identity negotiation and reconstruction. These new meanings explain the growing interest of student teachers in improving their ICTs skills.

Subsequently, ICTs should be at the heart of any reformation schemes of Egyptian teacher education. ICTs should be invested to assist student teachers acquire flexible knowledge and skills, self-direct learning, and co-operate with peers to become life-long learners (Orhun, 2003). In the current context, student teachers need to get over their alienation from their computer devices and to start to build up a personal link with their machines to be able to grow a pedagogical and practical sensitivity toward the benefits ICTs can provide. Reaching to the moment when student teachers will interact intellectually with their ICTs and explore the artificial intelligence lie in these devices and fully invest its energy to improve their academic and professional performance.

This conclusion is supported by results presented in Table 3 where most student teachers dismiss the suggestion that mobile phones can be used for academic purposes. Yet, in examining results we find that both male and female student teachers use mobile phones to exchange academic knowledge and information and to engross in academic discussions.

Based on the previous analysis of student teachers' responses it became clear that the anticipated transformation in Egyptian student teachers' ICTs competencies need time to construct the required knowledge foundation and develop the necessary practical skills. Also, dispersed workshops and training program, as International Computer Driving License (ICDL), are no longer sufficient to launch a real change in student teachers' ICTs competences. On the contrary, continuous and sustained training is needed so student teachers become comfortable and efficient in implementing ICTs (Janssens-Bevernage et al., 2010). This training should combine technological training with openness and acceptance of change (Judge \& O’Bannon, 2007; Vannatta \& Fordham, 2004).

Results in Table 4, 5 and 10 sustain this proposition where a high proportion of student teachers expressed their unreadiness to integrate ICTs into their teaching practice because of the lack of proper ICTs' training. These findings echo results emerged from many researches mentioned earlier, that student teachers need to be provided with sufficient ICTs training in order to increase their readiness to implement efficiently ICTs into their future education (Enochsson, 2010; Janssens-Bevernage et al., 2010; Shah \& Mahmood, 2016). Therefore, in Table 7 and 8 we witnessed a consensus among student teachers that free access to university computer laps and training courses are crucial to the enhancement ICTs skills.

Consequently, student teachers demand developing administration policies that enforce the implementation of 
ICTs into teacher education courses. And faculty members are compelled to integrate ICTs into their teaching and other academic activities, so that new teachers won't need to spend more time on acquiring the required ICTs skills. In this case, ICTs in teaching will become a natural part of the daily teaching practice in all education institutions (Beriswill et al., 2016; Brun \& Hinostroza, 2014). This also will make student teachers comfortable in adopting updated teaching techniques. Therefore, all chances since enrollment till graduation must be exploited to train student teachers on new teaching techniques that encompass the implementation of ICTs. This will guarantee that everyday class will substitutes the learning outcomes of ICTs training program (Derya-Orhan \& Kurt, 2017; Doerksen, 2016).

However, faculty members must be aware that this transformation process can cause frustration, anxiety and tension, if student teachers feel that they don't possess the required technical skills which in return make them feel embarrassed. Therefore, faculty members should address these issues while working on building student teachers' ICTs skills (Jacobson-Lundeberg, 2016).

\section{Conclusion}

To finalize this debate, results generated in this research authenticate the growing awareness Asyut student teachers developed about ICTs and how it has become a substantial component of everyday 21 st century education experience. They understand that it has become their gateway to the 21 st century teaching platform. In the meantime, they recognize that their ability to successfully integrate ICTs into their teaching practice is a complex and multifaceted process. Brinkerhoff (2006) identified four key factors that control the fruitful investment of ICTs into teaching, as follows: 1) resources; 2) training and experience; 3) institutional support; and 4) attitude and personal demeanors. Asyut student teachers interpret these factors, as follows:

Free and open-access ICTs laps are the most significant factor in whether student teachers use them or not. The most significant factor for continuing the development of student teachers' ICTs skills is to secure free, 24 hours access to updated ICTs equipment. Taking into consideration the financial status of many student teachers; Asyut University is obliged to provide the faculty of education with well-equipped computer laps.

As for female student teachers, cultural factors must count as well as economic ones. It is important to specify computer laps to female students only, or to divide computer laps' working hours between male and female student teachers. So, families can rest their minds that their daughters' chastity and virtue are well preserved.

Learning ICTs takes time. Introducing and using ICTs is a time-consuming process. Student teachers need time to become comfortable in integrating ICTs into their academic and professional life. Student teachers need extensive, on-going exposure to ICTs to be able to evaluate and select the most appropriate way of performance.

Preparing student teachers to fruitfully invest ICTs into their teaching exceeds improving their technical skills. Student teachers need more than mere technical ICTs training. They need to be trained on how to use ICTs pedagogically. Therefore, pedagogical training program on efficient integration of ICTs into teaching is very crucial.

Training is critically important. On-going, relevant professional ICTs training is essential for enhancing student teachers' ICTs skill acquisition and implementation.

ICTs must be invested constructively to transform teacher education. Student teachers' ICTs competencies can be improved significantly if technology is well integrated in their daily classroom. Well integration of ICTs into teachers' education leads to better ICTs performance and investment. Therefore, shifting pedagogies, redesigning teacher education curricula and adopting new methods of assessment are essential to optimize the use of ICTs and to transform teacher education.

At the end, the growing importance of ICTs has placed increasing emphasis on the need to ensure that Egyptian teachers become information literate. Therefore, teacher education is confronted with a major challenge that is to provide formal instruction in information technology, visual and technological literacy, as well as in how to create meaningful content with modern technology. On the other hand, Egyptian education institution is obliged to adopt and develop new techniques of teaching, and continuously evaluate the taught ICTs skills at all levels of education. Teachers on their behalf must continue their engagement in training, mentoring, and professional development.

Egypt as the rest of developing countries is eager to adopt technology. It continues to put efforts in planning and implementing innovative strategies that focus on integrating ICTs in all life aspects. This research adds to the body of literature in a few ways. Through analyzing the gains and drawbacks, Egyptian teacher education experienced in its attempt to integrate ICTs into teachers' preparation process. The current research recommends: first, improving the existing training mechanism; second, ensuring funds will have the biggest impact on the largest number of student teachers; finally, getting training right is a priority. 


\section{References}

Abdelaziz, H. A. (2012). The effect of computer-mediated instructions and webquest on pre-service buiseniss educaiton teachers' self-directed learning readiness and teaching performacne Delta Pi Epsilon Journal, 54(1), 1-15.

Al-Azawei, A., Parslow, P., \& Lundqvist, K. (2016). Barriers and Opportunities of E-Learning Implementation in Iraq: A Case of Public Universities. International Review of Research in Open and Distance Learning, 17(5). https://doi.org/10.19173/irrodl.v17i5.2501

Al-busaidi, K. A., \& Al-shihi, H. (2012). Key factors to instructors' satisfaction of learning management systems in blended learning. Journal of Computing in Higher Education, 24(1), 18-39. https://doi.org/10.1007/s12528-011-9051-X

Ale, K., Loh, Y. A.-C., \& Chib, A. (2017). Contextualized-OLPC education project in rural India: measuring learning impact and mediation of computer self-efficacy. Educational Technology, Research and Development, 65(3), 769-794. https://doi.org/10.1007/s11423-017-9517-2

Bakir, N. (2016). Technology and Teacher Education: A Brief Glimpse of the Research and Practice that Have Shaped the Field. TechTrends, 60(1), 21-29. https://doi.org/10.1007/s11528-015-0013-4

Beriswill, J. E., Bracey, P. S., Sherman-morris, K., Huang, K., \& Lee, S. J. (2016). Professional Development for Promoting 21st Century Skills and Common Core State Standards in Foreign Language and Social Studies Classrooms. TechTrends, 60(1), 77-84. https://doi.org/10.1007/s11528-015-0004-5

Bradshaw, P., Younie, S., \& Jones, S. (2013). Open education resources and higher education academic practice. Campus - Wide Information Systems, 30(3), 186-193. https://doi.org/10.1108/10650741311330366

Brinkerhoff, J. (2006). Effects of a long-duration, professional development academy on technology skills, computer self-efficacy, and technology integration beliefs and practices. Journal of Research on Technology in Education, 39(1), 22-43. https://doi.org/10.1080/15391523.2006.10782471

Brun, M., \& Hinostroza, J. E. (2014). Learning to become a teacher in the 21st century: ICT integration in Initial Teacher Education in Chile. Journal of Educational Technology \& Society, 17(3), 222-238.

Buabeng-Andoh, C. (2012). Factors influencing teachers' adoption and integration of information and communication technology into teaching: A review of the literature. International Journal of Education and Development using Information and Communication Technology, 8(1), 136-155.

Chen, J.-Q., \& Chang, C. (2008). Testing the whole teacher approach to professional development: A study of enhancing early childhood teachers' technology proficiency. Journal of Early Childhood Research \& Practice, $8(1)$.

Coplin, B. (2003). 10 Things Employers Want you to Learn in College: The Know-How You Need to Succeed. Berkeley, CA: Ten Speed Press.

Darling-Hammond, L. (2001). Educating teachers for California's future. Teacher Education Quarterly, $28(1), 9$.

Dela Rosa, J. P. O. (2016). Experiences, perceptions and attitudes on ICT integration: A case study among novice and experienced language teachers in the Philippines. International Journal of Education and Development using Information and Communication Technology, 12(3), 37-57.

Derya-Orhan, G., \& Kurt, A. A. (2017). The Relationship Between Pre-Service Teachers' Use of 21st Century Learner Skills and 21st Century Teacher Skills. Egitim ve Bilim, 42(190).

Doerksen, R. (2016). Lookning inward to 21st century pedagogy. McGill Journal of Education (Online), 51, 1197-1203.

Downes, T. E. A. (2002). Making Better Connections. DEST, Canberra. Retrieved from http://www.dest.gov.au/schools/publications/2002/prof essional.htm

El Ebyary, K. M. (2013). Profiling Formative Assessment Culture in EFL Teacher Education Programs in the Middle East. Theory and Practice in Language Studies, 3(12), 2169-2177. https://doi.org/10.4304/tpls.3.12.2169-2177

Enochsson, A.-B. (2010). ICT in Initial Teacher Training: Sweden Country report.

Fosnot, C. T., \& Perry, R. S. (Eds.). (2005). Constructivism: A psychological theory of learning. New York, NY: Teacher College Press. 
Fuad-Ismail, A., \& Ajrami, S. J. (2017). The Degree of Implementing ISTE Standards in Technical Education Colleges of Palestine. TOJET : The Turkish Online Journal of Educational Technology, 16(2).

Giroux, H. A. (2005). Cultural studies in dark times: Public pedagogy and the challenge of Neoliberalism. Retrieved from https://www.henryagiroux.com/online_articles/DarkTimes.htm

Hani, N. (2014). Benefits and barriers of computer-assisted language learning and teaching in the Arab World: Jordan as a model. Theory and Practice in Language Studies, 4(8), 1609-1615. https://doi.org/10.4304/tpls.4.8.1609-1615

Hattab, H., Krby, D., Gohar, A., \& EL Shorbagi, S. (2012). Golabal enterpreneureship monitor: Egypt enterpreneurship report 2010. Retrieved from https://pdf.usaid.gov/pdf_docs/PA00HRTV.pdf

Henriksen, D., Mishra, P., \& Fisser, P. (2016). Infusing Creativity and Technology in 21st Century Education: A Systemic View for Change. Journal of Educational Technology \& Society, 19(3), 27-37.

Herrera, L. (2012). Youth and Citizenship in the Digital Age: A View from Egypt. Harvard Educational Review, 82(3), 333-352,438. https://doi.org/10.17763/haer.82.3.88267r117u710300

Husin, W. N. F. W., Arsad, N. M., Othman, O., Halim, L., Rasul, M. S., Osman, K., \& Iksan, Z. (2016). Fostering students' 21st century skills through Project Oriented Problem Based Learning (POPBL) in integrated STEM education program. Asia - Pacific Forum on Science Learning and Teaching, 17(1), 1-18.

Internet World States. (2018). Internet Users Statistics for Africa: Africa Internet Usage, 2018 Population Stats and Facebook Subscribers. Retrieved from https://www.internetworldstats.com/stats1.htm

Jacobson-Lundeberg, V. (2016). Pedagogical Implementation of 21st Century Skills. Educational Leadership and Administration, 27, 82-IV.

Janssens-Bevernage, A., Cornille, B., \& Mwaniki, N. (2010). Integrating ICT in teacher training: Reflections on practice and policy implications - A Case Study of the learning resource centre at the Kenya Technical Teachers College. Retrieved from http://www.idrc.ca/en/ev-93060-201-1-DO_TOPIC.html

Judge, S., \& O'Bannon, B. (2007). Integrating technology into field-based experiences: A model that fosters change. Computers in Human Behavior, 23, 286-302. https://doi.org/10.1016/j.chb.2004.10.013

Kalogiannakis, M. (2010). Training with ICT for ICT from the trainee's perspective. A local ICT teacher training $\begin{array}{lllll}\text { experience. Education and Information } & \text { Technologies, } & 15(1), & 3-17 .\end{array}$ https://doi.org/10.1007/s10639-008-9079-3

Kay, K., \& Honey, M. (2005). Beyond technology competency: A vision of ICT literacy to prepare students for the 21 st century. Charleston, W.V: Evantia.

Kirby, D., \& Ibrahim, N. (2012). An enterprise revolution for Egyptian universities. Education, Business and Society: Contemporary Middle Eastern Issues, 5(2), 98-111. https://doi.org/10.1108/17537981211251142

Ladyshewsky, R. K. (2006). Peer coaching: A constructivist methodology for enhancing critical thinking in postgraduate business education. Higher Education Research \& Development, 25(1), 67-84. https://doi.org/10.1080/13600800500453196

Lee, K.-W. (2000). English teachers' barriers to the use of Computer-assisted Language Learning. Retrieved from http://iteslj.org/Articles/Lee-CALLbarriers.html

Liu, L. B., Baker, L. L., \& Milman, N. B. (2014). Technological innovation in twenty-first century multicultural teacher preparation. Journal for Multicultural Education, 8(1), 54-67. https://doi.org/10.1108/JME-02-2013-0005

Marsh, T. E. J. (2014). The Neoliberal education project and the rise of revolution: Lessons from the youth of Egypt. Planning and Changing, 45(3/4), 381-404.

MCIT. (2008). The Future of Internet Economy in Egypt, official report for the Egyptian Ministry of Communication and Information Technology.

MCIT. (2010). Egyptian Education Initiative, official report for the Egyptian Ministry of Communication and Information Technology.

Minstry of Communications and Information Technology. (2006). Capacity Building. Retrieved from https://www.mcit.gov.eg

Muhammad-Iqbal, M., Fazal, S., \& Muhammad-Saeed, K. (2013). Implementation of Information and 
Communication Technologies (ICTs) in Education Course: A Case from Teacher Education Institutions in Pakistan. Bulletin of Education and Research, 35(2).

Murphy, E., \& Rodriguez-Manzanares, M. A. (2009). Sage without a stage: Expanding the object of teaching in a web-based, high-school classroom. International Review of Research In Open And Distance Learning, 10(3), 1-19. https://doi.org/10.19173/irrodl.v10i3.579

Orhun, E. (2003). Computer-based cognitive tolls in teacher training: The COG-TECH projects. The Turkish Online Journal of Educational Technology, 2(3), 35-40.

Pouezevara, S., Mekhael, S. W., \& Darcy, N. (2014). Planning and Evaluating ICT in Education Programs Using the Four Dimensions of Sustainability: A Program Evaluation from Egypt. International Journal of Education and Development using Information and Communication Technology, 10(2), 120-141.

Rautopuro, J., Pöntinen, S., \& Kukkonen, J. (2006). Towards the Information Society--the Case of Finnnish Teacher Education. Informatics in Education, 5(2), 297.

Robson, C. (1997). Real world research: A resource for social scientists and practitioner-researchers. Oxford: Blackwell.Robson, C..

Sallam, H. (2013). The Egyptian Revolution and the Politics of Histories. PS, Political Science \& Politics, 46(2), 248-258. https://doi.org/10.1017/S1049096513000231

Schomaker, R. (2015). Accreditation and quality assurance in the Egyptian higher education system. Quality Assurance in Education, 23(2), 149-165. https://doi.org/10.1108/QAE-08-2013-0034

Shah, S. R., \& Mahmood, K. (2016). Contributing factors in knowledge sharing for performance of university students in teachers' training programs. Library Management, 37(8/9), 496-506.

Tayie, S., Pathak-Shelat, M., \& Hirsjarvi, I. (2012). Young People's Interaction with Media in Egypt, India, Finland, Argentina and Kenya/La interacción de los jóvenes con los medios en Egipto, India, Finlandia, Argentina y Kenia. Comunicar, 20(39), 53-62. https://doi.org/10.3916/C39-2012-02-05

Thormann, J., \& Fidalgo, P. (2014). Guidelines for Online Course Moderation and Community Building from a Student's Perspective. Journal of Online Learning \& Teaching, 10(3), 374-388.

Timmons, J. (1989). The Entrepreneurial Mind. Andover, MA: Brick House Publishing.

Topolovčan, T., \& Matijević, M. (2017). Critical Thinking as a Dimension of Constructivist Learning: Some of the Characteristics of Students of Lower Secondary Education in Croatia. [Kritično mišljenje kot dimenzija konstruktivističnega učenja: nekatere značilnosti učencev predmetne stopnje osnovne šole na Hrvaškem]. CEPS Journal : Center for Educational Policy Studies Journal, 7(3), 47-66.

Trucano, M. (2005). Knowledge Maps: ICTs in Education: What Do We Know About the Effective Uses of Information and Communication Technologies in Education in Developing Countries. Retrieved from https://eric.ed.gov/?id=ED496513

Udanor, C., Aneke, S., \& Ogbuokiri, B. O. (2016). Determining social media impact on the politics of developing countries using social network analytics. Program, 50(4), 481-507. https://doi.org/10.1108/PROG-02-2016-0011

Vannatta, R. A., \& Fordham, N. (2004). Teacher dispositions as predictors of classroom technology use. Journal of Research on Technology in Education, 36(3), 253-271. https://doi.org/10.1080/15391523.2004.10782415

Venkatesh, V., Rabah, J., Fusaro, M., Couture, A., Varela, W., \& Alexander, K. (2016). Factors impacting university instructors' and students' perception of course effectiveness and technology integration in the age of WEB 2.0. McGill Journal of Education (Online), 51(1), 533-561. https://doi.org/10.7202/1037358ar

Waly, S. G. (2013). Reflections of EFL university instructors on teaching and learning after the revolution in Egypt. Education, Business and Society: Contemporary Middle Eastern Issues, 6(1), 4-14. https://doi.org/10.1108/17537981311314673

Winter 2016). Factors impacting university instructors' and students' perceptions of course effectiveness and technology integration in the age of Web 2.0. McGill Journal of Education (Online), 51, 533-561.

World Economic Forum. (2009). Global Education Initiative.

Yuksel, G., Yildirim, S., \& Yildirim, Z. (2009). Main Barriers and Possible Enablers of ICTs Integration into Pre-service Teacher Education Programs. Journal of Educational Technology \& Society, 12(1), 193. 


\section{Copyrights}

Copyright for this article is retained by the author(s), with first publication rights granted to the journal.

This is an open-access article distributed under the terms and conditions of the Creative Commons Attribution license (http://creativecommons.org/licenses/by/4.0/). 